\title{
A biological extract of turmeric (Curcuma longa) modulates response of cartilage explants to lipopolysaccharide
}

\author{
Wendy Pearson ${ }^{1 *}$ (D) and Laima S. Kott ${ }^{2}$
}

\begin{abstract}
Background: Turmeric is commonly used as a dietary treatment for inflammation, but few studies have evaluated the direct effect of turmeric on cartilage. The purpose of this study was to characterize cartilage explants' inflammatory responses to lipopolysaccharide in the presence of a simulated biological extract of turmeric.

Methods: Turmeric was incubated in simulated gastric and intestinal fluid, followed by inclusion of liver microsomes and NADPH. The resulting extract $\left(T U R_{\text {sim }}\right)$ was used to condition cartilage explants in the presence or absence of lipopolysaccharide. Explants were cultured for $96 \mathrm{~h}$ (h); the first $24 \mathrm{~h}$ in basal tissue culture media and the remaining 72 $\mathrm{h}$ in basal tissue culture media containing $\operatorname{TUR}_{\text {sim }}(0,3,9$ or $15 \mu \mathrm{g} / \mathrm{mL})$. Lipopolysaccharide $(0 \mathrm{or} 5 \mu \mathrm{g} / \mathrm{mL})$ was added for the final $48 \mathrm{H}$. media samples were collected immediately prior to lipopolysaccharide exposure $(0 \mathrm{~h})$ and then at 24 and $48 \mathrm{~h}$ after, and analyzed for prostaglandin $\mathrm{E}_{2}\left(\mathrm{PGE}_{2}\right)$, glycosaminoglycan (GAG), and nitric oxide (NO). Explants were stained with calcein-AM for an estimate of live cells. Data were analyzed using a 2-way repeated measures (GAG, PGE NO) or 1-way ANOVA without repeated measures (viability). Significance accepted at $p<0.05$.
\end{abstract}

Results: $\mathrm{TUR}_{\text {sim }}$ significantly reduced $\mathrm{PGE}_{2}, \mathrm{NO}$ and $\mathrm{GAG}$, and calcein fluorescence was reduced. Conclusions: These data contribute to the growing body of evidence for the utility of turmeric as an intervention for cartilage inflammation.

Keywords: Arthritis, Cartilage inflammation, Simulated digestion, Hepatic metabolism, Turmeric

\section{Background}

Turmeric (Curcuma longa) is a South Asian perennial herb of the ginger family. Contemporary research providing evidence for the anti-inflammatory and anti-arthritic effects of turmeric first appeared in the scientific literature almost half a century ago $[1,2]$. Since then more than 1100 research studies have been documented which describe antiinflammatory effects of turmeric and/or its principle bioactive curcumin. Several recent reviews of the literature pertaining to turmeric and/or curcumin [3-6] unanimously conclude that the research evidence supports their systemic anti-inflammatory and anti-arthritic effects. There are, however, few studies that explore direct effects of turmeric on cartilage independent of systemic anti-inflammatory activity. These studies are important as they serve to illuminate

\footnotetext{
* Correspondence: wpearson@uoguelph.ca

1 Department of Animal Biosciences, University of Guelph, Guelph, ON N1G 2W1, Canada

Full list of author information is available at the end of the article
}

mechanism of anti-arthritic action on the target tissue. Two studies have reported effects of curcumin on equine [7] and human [8] cartilage explants. Conditioning of equine cartilage explants with curcumin $(100 \mu \mathrm{mol} / \mathrm{L})$ for 5 days significantly reduced interleukin-(IL-) $1 \beta$-induced release of glycosaminoglycan (GAG; a measure of cartilage breakdown) [7]. This inhibition of GAG release was not observed in human cartilage explants, perhaps due to a lower curcumin exposure rate $(5-20 \mu \mathrm{mol} / \mathrm{L})$, but these authors did report an inhibition of IL-1-induced nitric oxide (NO), prostaglandin $\mathrm{E}_{2}\left(\mathrm{PGE}_{2}\right)$, IL-6, IL-8 and matrix metalloproteinase 3 [8]. While these 2 studies provide rationale for further investigating direct effects of curcumin on cartilage, their usefulness is limited by the fact that neither study accounted for the fact that curcumin is in most cases provided orally. This oral route of administration exposes curcumin to enzymatic and $\mathrm{pH}$-mediated alteration, the effects of which are not accounted for in the previous 2 studies.

(c) The Author(s). 2019 Open Access This article is distributed under the terms of the Creative Commons Attribution 4.0 International License (http://creativecommons.org/licenses/by/4.0/), which permits unrestricted use, distribution, and reproduction in any medium, provided you give appropriate credit to the original author(s) and the source, provide a link to the Creative Commons license, and indicate if changes were made. The Creative Commons Public Domain Dedication waiver (http://creativecommons.org/publicdomain/zero/1.0/) applies to the data made available in this article, unless otherwise stated. 
Furthermore, the effects of turmeric (the parent material of curcumin) on cartilage explants has not been investigated.

It is hypothesized that turmeric reduces inflammation in cartilage, and this effect is not muted by the effects of gastrointestinal digestion or hepatic metabolism. The purpose of the current experiment was to evaluate direct anti-inflammatory effects of a simulated biological extract of turmeric on cartilage explants.

\section{Methods}

All chemical reagents were purchased from Sigma Aldrich Canada (Oakville ON) unless otherwise indicated. All spectrophotometric and fluorescence analyses were conducted using a 1420 Victor 2 spectrophotometer (Perkin Elmer; Woodbridge ON). Turmeric was purchased from Amoros Nature, S.L. Hostaliric-Girona, Spain (Lot number 16.01744; Certificate of Analysis provided in Supplementary Files).

\section{Biological extraction}

A biological extract of turmeric was prepared in a manner to simulate upper gastrointestinal digestion (stomach and small intestine) and first pass biotransformation by the liver, as previously described [9]. Briefly, turmeric $(0.10 \mathrm{~g})$ (Selected Bioproducts Inc. Guelph ON) was incubated on a tube rocker in $15 \mathrm{~mL}$ of simulated gastric fluid ( $37 \mathrm{mM} \mathrm{NaCl}, 0.03 \mathrm{~N} \mathrm{HCl}, 3.2 \mathrm{mg} / \mathrm{mL}$ pepsin) at $37^{\circ} \mathrm{C}$ for $2 \mathrm{~h}$. Subsequently, $\mathrm{pH}$ was adjusted to 7.0 and an equal volume of simulated intestinal fluid $(30 \mathrm{mM}$ $\mathrm{K}_{2} \mathrm{HPO}_{4}, 160 \mathrm{mM} \mathrm{NaH} \mathrm{PO}_{4}, 20 \mathrm{mg} / \mathrm{mL}$ pancreatin) was added, and the mixture was incubated on a tube rocker at $37^{\circ} \mathrm{C}$ for an additional $2 \mathrm{~h}$. Liver microsomes (from male rat, purchased from Sigma Aldrich; catalogue number M9066) and NADPH were then added, and the mixture was incubated for an additional $30 \mathrm{~min}$. Finally the mixture was centrifuged and the supernatant filtered through a $50 \mathrm{kDa}$ centrifuge filtration unit (Amicon Ultra) and refrigerated until use.

\section{Cartilage explants}

Front limbs from 8 pigs were obtained post-mortem from a federally-inspected meat processing facility within $1 \mathrm{~h}$ of humane slaughter for the purpose of human food. Limbs were transported on ice to the laboratory, the intercarpal joint was exposed, and explants were aseptically excised from both articulating surfaces using a 4 $\mathrm{mm}$ dermal biopsy tool. Explants were arranged ( 2 per well) in 24-well tissue culture plates containing $1000 \mu \mathrm{L} /$ well of DMEM supplemented with amino acids, sodium bicarbonate, pen/strep, glutamine, ascorbic acid and 10\% FBS as previously described [9]. Media was removed and refreshed from wells every $24 \mathrm{~h}$ for a total culture duration of $96 \mathrm{~h}$.
After the first $24 \mathrm{~h}$ of culture, and for each day there-

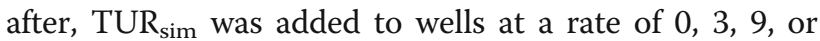
$15 \mu \mathrm{g} / \mathrm{mL}$ such that tissue from each animal was exposed to each dose. Assuming a total body water fluid volume of $45 \%$ ( $36 \mathrm{~L}$ in a $80 \mathrm{~kg}$ human), these inclusion rates approximate a human bioavailable turmeric dose of 108 , 324 and $540 \mathrm{mg}$, respectively. During the final $48 \mathrm{~h}$ of culture, an inflammatory stimulus [lipopolysaccharide (LPS)] (0 or $5 \mu \mathrm{g} / \mathrm{mL}$ ) was added to the wells.

\section{Sample analysis}

Media samples from the final $48 \mathrm{~h}$ of culture were analyzed for $\mathrm{PGE}_{2}$, GAG, and NO (Griess reaction). Immediately following the final collection of media, explants were placed into 96-well micro-titre plates and incubated with $200 \mu \mathrm{L}$ of $4 \mathrm{mM}$ calcein for $40 \mathrm{~min}$ for an estimate of viability of chondrocytes within explants. Calcein fluorescence was obtained using excitation/emission filters of $485 / 530 \mathrm{~nm}$.

Media $\mathrm{PGE}_{2}$ concentrations were determined using a commercially-available ELISA kit (R\&D Systems; Cat \# KGE004B) according to manufacturer instructions. A best-fit 3rd order polynomial standard curve was developed for each plate $\left(R^{2} \geq 0.99\right)$, and these equations were used to calculate $\mathrm{PGE}_{2}$ concentrations for samples from each plate.

GAG concentrations were determined with the 1,9-dimethyl methylene blue (DMB) staining assay. Samples were added to 96 -well microtitre plates at $50 \%$ dilution, then serially diluted 1:2 up to a final dilution of 1:64. Guanidine hydrochloride $(275 \mathrm{mg} / \mathrm{mL})$ was added to each well, followed immediately by addition of $150 \mu \mathrm{L}$ DMB reagent. Absorbance was measured at $530 \mathrm{~nm}$. Sample absorbance was compared to that of a bovine chondroitin sulfate standard. A best-fit linear standard curve was developed for each plate and these equations were used to calculate GAG concentrations for samples.

Nitrite $\left(\mathrm{NO}^{2-}\right)$, a stable oxidation product of $\mathrm{NO}$, was analyzed by the Griess Reaction. Undiluted samples were added to 96 -well microtitre plates. Sulfanilamide $(0.01 \mathrm{~g} /$ $\mathrm{mL}$ ) and $\mathrm{N}-(1)$-Napthylethylene diamine hydrochloride $(1 \mathrm{mg} / \mathrm{mL})$ dissolved in phosphoric acid $(0.085 \mathrm{~g} / \mathrm{L})$ was added to all wells, and absorbance was read within $5 \mathrm{~min}$ and $530 \mathrm{~nm}$. Sample absorbance was compared to a sodium nitrite standard. A best-fit linear standard curve was developed for each plate, and these equations were used to calculate nitrite concentrations for samples.

\section{Data analysis}

Data are presented as means \pm SEM unless otherwise noted. Time ' 0 h' represents the media sample obtained immediately prior to inclusion of LPS, while time 24 and $48 \mathrm{~h}$ represent media samples 24 and $48 \mathrm{~h}$ after exposure to LPS. PGE 2 , GAG and NO data were analyzed using a 
2-way repeated measures (with respect to treatment and time) ANOVA. Viability data were analyzed using a oneway ANOVA. When a significant F-ratio was obtained the Holm-Sidak post-hoc test was used to identify significantly different means. Significance was accepted when $p<0.05$.

\section{Results}

\section{$\mathrm{PGE}_{2}$}

Stimulation of control explants with LPS produced a significant increase in $\mathrm{PGE}_{2}$ at 24 and $48 \mathrm{~h}$ (Fig. 1a and b). Conditioning of explants with $\mathrm{TUR}_{\text {sim }}(15 \mu \mathrm{g} / \mathrm{mL})$ significantly reduced LPS-induced $\mathrm{PGE}_{2}$ at 24 and $48 \mathrm{~h}$. TUR $_{\text {sim }}$ (3 and $9 \mu \mathrm{g} / \mathrm{mL}$ ) also significantly inhibited $\mathrm{PGE}_{2}$ production at $48 \mathrm{~h}$ (Fig. 1a). Conditioning with $\mathrm{TUR}_{\text {sim }}$ did not affect $\mathrm{PGE}_{2}$ production in explants not stimulated with LPS (Fig. 1b).

\section{GAG}

Stimulation of control explants with LPS produced a significant increase in GAG at 24 and $48 \mathrm{~h}$ (Fig. 2a and b) compared with unstimulated controls (Fig. 2a). In explants not stimulated with LPS, TUR sim $(9$ and $15 \mu \mathrm{g} / \mathrm{mL}$ ) significantly reduced overall GAG compared with unstimulated controls; media GAG was significantly lower in unstimulated explants conditioned with $\mathrm{TUR}_{\text {sim }}(15 \mu \mathrm{g} / \mathrm{mL})$ at 48 h compared with unstimulated controls (Fig. 2b).

\section{NO}

Stimulation of control explants with LPS $(5 \mu \mathrm{g} / \mathrm{mL})$ produced a significant increase in $\mathrm{NO}$ at 24 and $48 \mathrm{~h}$ (Fig. 3a). This increase was not seen in explants conditioned with $\mathrm{TUR}_{\text {sim }}$ (3 and $\left.9 \mu \mathrm{g} / \mathrm{mL}\right)$, and $\mathrm{TUR}_{\text {sim }}(15 \mu \mathrm{g} / \mathrm{mL})$ prevented increase in LPS-induced NO production only at
$48 \mathrm{~h}$. There were no significant differences between any dose of $\mathrm{TUR}_{\text {sim }}$ and stimulated control explants at any time point.

\section{Viability}

Stimulation of control explants with LPS $(5 \mu \mathrm{g} / \mathrm{mL})$ for $48 \mathrm{~h}$ resulted in a significant $(p=0.01)$ decline in calcein fluorescence (a measure of cell viability) (Fig. 4). There was no difference in calcein flourescence amongst all LPS-stimulated explants irrespective of exposure to TUR $_{\text {sim }}$ (Fig. 4a). However, in unstimulated explants TUR $_{\text {sim }}$-conditioning ( 3 and $9 \mu \mathrm{g} / \mathrm{m}$ ) resulted in a significant decline in viability (Fig. 4).

\section{Discussion}

The main findings of this study are that cartilage explants, when exposed to a biological extract of turmeric in the presence of LPS, produced various reductions in $\mathrm{PGE}_{2}$, GAG and NO compared with LPS-stimulated controls. Furthermore, unstimulated explants had reduced GAG loss and reduced staining with calcein-AM.

In the current study we utilized methodology which provides a reasonable approximation for the effects of upper gastrointestinal digestion, hepatic metabolism and diffusion across the synovial membrane. Simulated digestion (gastric and intestinal) is an important consideration during in vitro evaluation of products or compounds that are typically consumed orally. It accommodates, at least in part, the effects of changing $\mathrm{pH}$ and enzymatic degradation on potentially bioactive compounds during digestion which may alter their effects on target tissues [10-12]. Furthermore, biotransformation and bioactivation by the liver can profoundly influence effects of dietary products on target tissues, and can be a
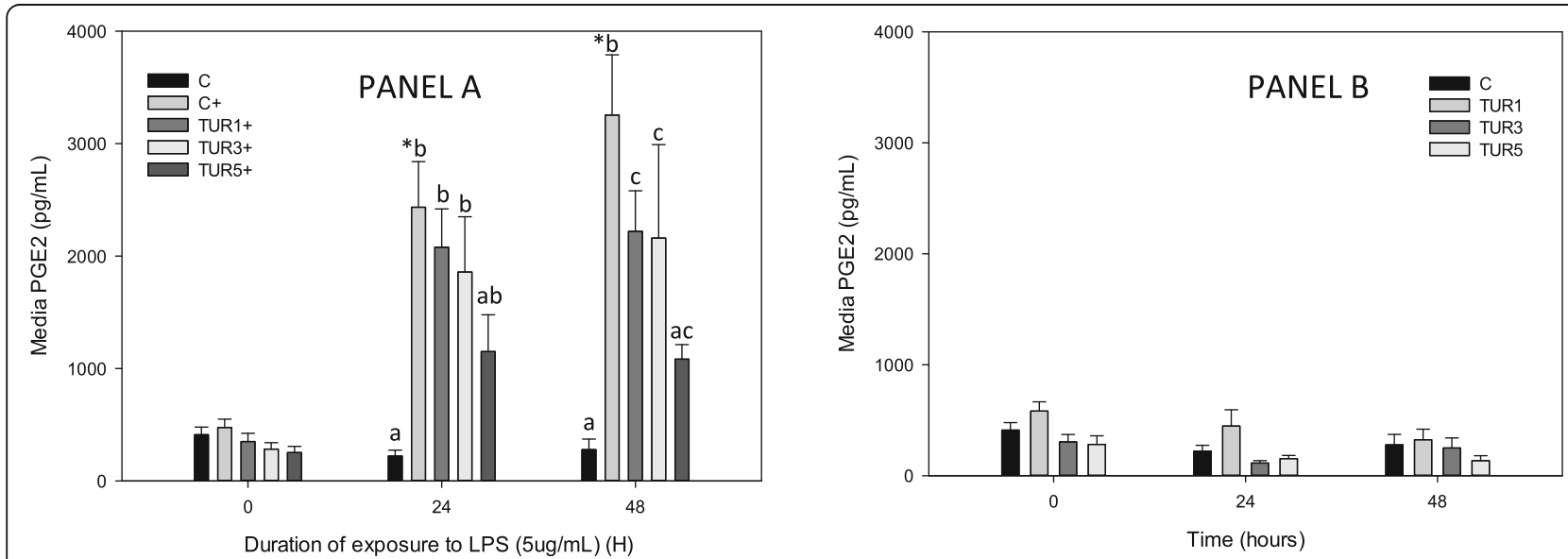

Fig. 1 PGE 2 production by cartilage explants ( $n=8$ pigs) conditioned with simulated biological extract of turmeric $(3,9 \mathrm{or} 15 \mu \mathrm{g} / \mathrm{mL}$; TUR1, TUR3 and TUR5 respectively) compared with simulated biological extract containing no turmeric (C) in the presence (Panel $\mathbf{a}$ ) or absence (Panel $\mathbf{b}$ ) of lipopolysaccharide (LPS; $5 \mu \mathrm{g} / \mathrm{mL}$ ) (+).Explants were cultured for a total of $96 \mathrm{~h}$ and were conditioned with TUR for the first $48 \mathrm{~h}$ prior to exposure to LPS. Data are shown for the final $48 \mathrm{~h}$ only. * denotes significant change from baseline within treatments. Letters denote significant differences between treatments at specific time points 


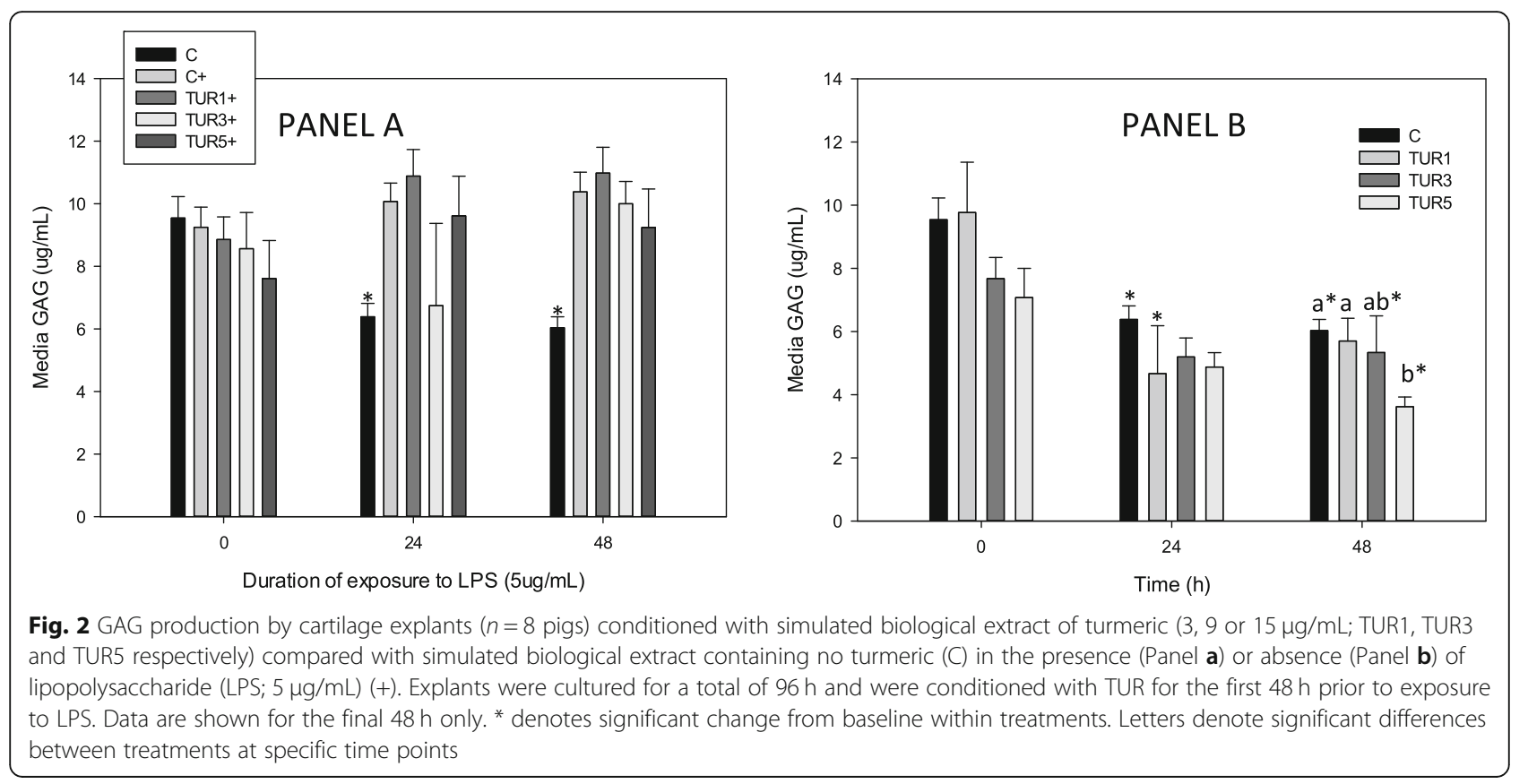

serious limitation to extrapolating in vitro data to in vivo situations [13]. We have previously demonstrated that the simulated hepatic metabolism step utilized in the current study effectively contributes to formation of 3 known post-hepatic biotransformation products of rosmarinic acid [9]. Thus we employed this methodology to trigger liver metabolism of potentially bioactive compounds within turmeric in the current study, and TURsim strongly inhibited LPS-induced $\mathrm{PGE}_{2}$ in a dosedependent manner. While curcumin is generally considered to be the bioactive compound in turmeric $[14,15]$, it undergoes extensive metabolism in the liver, producing curcumin glucuronide, curcumin sulfate, tetrahydrocurcumin, hexahydrocurcumin, octahydrocurcumin, and hexahydrocurcuminol $[16,17]$. Our observed inhibition of LPS-induced $\mathrm{PGE}_{2}$ by TUR $\mathrm{T}_{\text {sim }}$ is consistent with curcumin-induced inhibition of $\mathrm{PGE}_{2}$ production by human chondrocytes and human cartilage explants [8]. However, others have demonstrated that curcumin biotransformation products (tetrahydrocurcumin, curcumin sulfate and hexahydrocurcumin) have only a weak inhibitory effect on phorbol ester-induced $\mathrm{PGE}_{2}$ production in
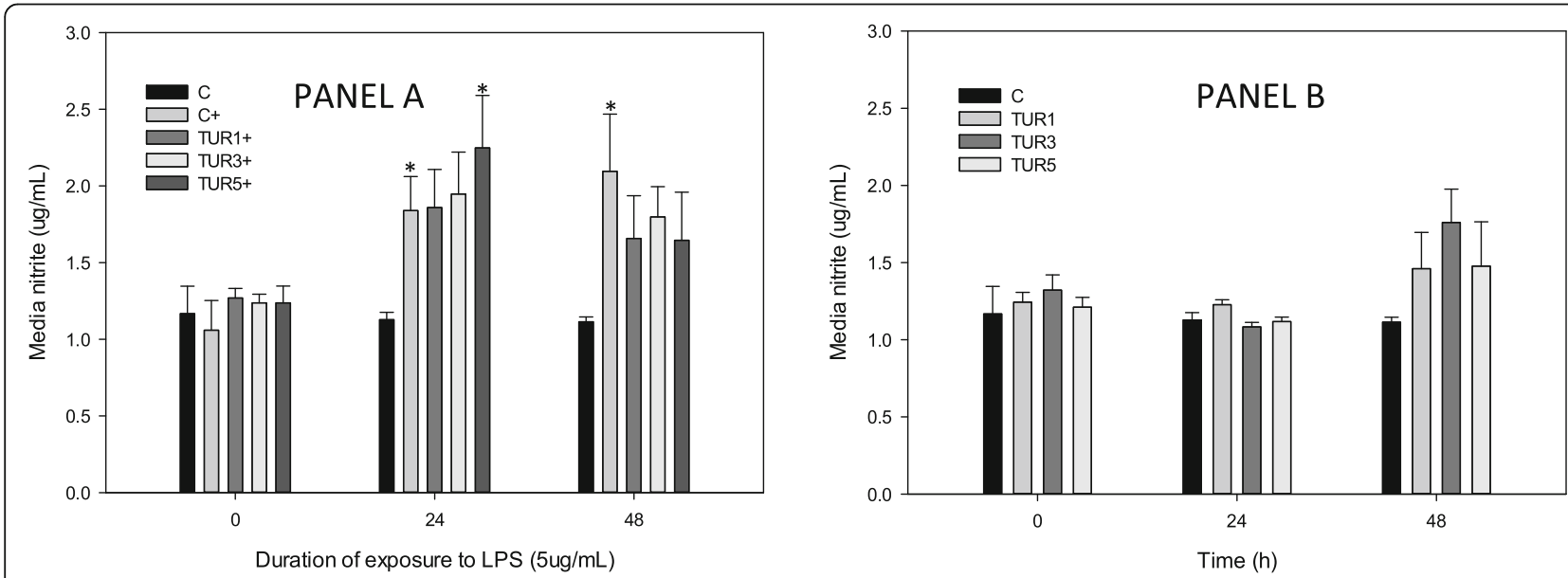

Fig. $3 \mathrm{NO}$ production by cartilage explants conditioned with simulated biological extract of turmeric (3, 9 or $15 \mu \mathrm{g} / \mathrm{mL}$; TUR1, TUR3 and TUR5 respectively) compared with simulated biological extract containing no turmeric (C) in the presence (Panel a) or absence (Panel b) of lipopolysaccharide (LPS; $5 \mu \mathrm{g} / \mathrm{mL}$ ). Explants were cultured for a total of $96 \mathrm{~h}$ and were conditioned with TUR for the first $48 \mathrm{~h}$ prior to exposure to LPS. Data are shown for the final $48 \mathrm{~h}$ only. ${ }^{*}$ denotes significant change from baseline 

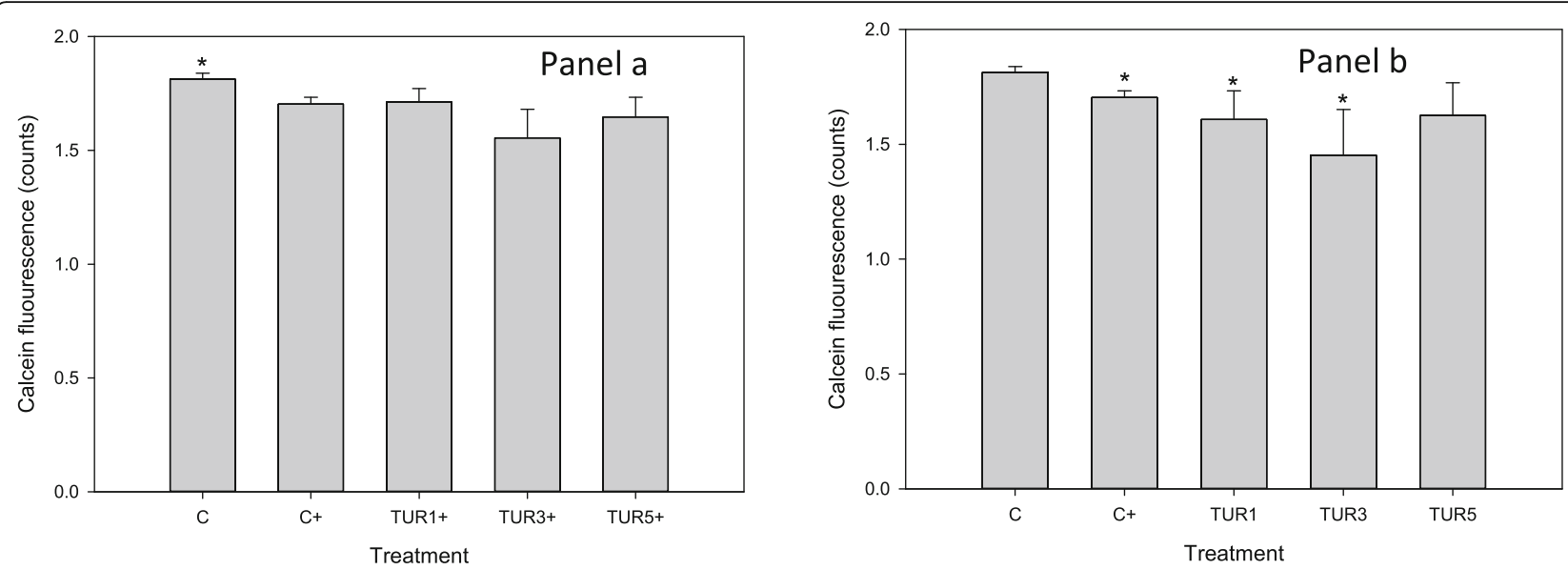

Fig. 4 Calcein staining (as a measure of cell viability) of cartilage explants conditioned with simulated biological extract of turmeric (3, 9 or $15 \mu \mathrm{g} /$ $\mathrm{mL}$; TUR1, TUR3 and TUR5 respectively) compared with simulated biological extract containing no turmeric (C) in the presence (Panel a) or absence (Panel b) of lipopolysaccharide (LPS; $5 \mu \mathrm{g} / \mathrm{mL}$ ). Explants were cultured for a total of $96 \mathrm{~h}$ and were conditioned with TUR for the first $48 \mathrm{~h}$ prior to exposure to LPS. ${ }^{*}$ denotes significant change from baseline

vivo [16], suggesting that post-hepatic curcumin is not the only product of turmeric digestion and metabolism contributing to our observed inhibition of $\mathrm{PGE}_{2}$. We did not characterize the post-hepatic species in our biological extract for the current study, and future research should attempt to identify the major phytochemical parents and downstream metabolic endproducts in $\mathrm{TUR}_{\text {sim }}$ to further define those with inhibitory effects on $\mathrm{PGE}_{2}$.

The slight inhibitory effect of TUR $\mathrm{Tim}_{\mathrm{sim}}(15 \mu \mathrm{g} / \mathrm{mL})$ on LPS-induced cartilage breakdown (as measured by increased release of GAG into tissue culture media) demonstrated in the current study is less marked than that reported for curcumin in IL-1-stimulated equine cartilage explants [7], perhaps due (at least in part) to the very high concentration of curcumin employed in the latter study $(100 \mu \mathrm{M}$, equivalent to $36.8 \mu \mathrm{g} / \mathrm{mL})$. Assuming a curcumin concentration of approximately $3 \%$ in turmeric powder [18], a curcumin concentration of $36.8 \mu \mathrm{g} /$ $\mathrm{mL}$ would be represented in a turmeric concentration of about $1227 \mu \mathrm{g} / \mathrm{mL}$ - markedly higher than the concentration of TUR sim $_{\text {in }}$ ine current study. The GAG inhibition observed at our highest dose occurred subsequent to an already-blunted GAG concentration prior to exposure to LPS, likely resulting from the $48 \mathrm{~h}$ of exposure to $\mathrm{TUR}_{\text {sim }}$ prior to stimulation with LPS. In unstimulated explants, the inhibition of GAG release was significant at the intermediate $(9 \mu \mathrm{g} / \mathrm{mL})$ and highest $(15 \mu \mathrm{g} /$

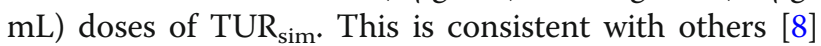
who report that curcumin $(5-20 \mu \mathrm{M}$, equivalent to $1.8-$ $7.4 \mu \mathrm{g} / \mathrm{mL}$ ) did not significantly inhibit IL-1-induced GAG release from human cartilage explants, but did reduce GAG loss in unstimulated explants. This result may arise, at least in part, from a reported inhibitory effect of curcumin on matrix metalloproteinases that facilitate disassembly of matrix proteoglycans [5]. The effect of post-hepatic transformation products of turmeric and/or its bioactive principles on GAG release from cartilage has not been previously reported and should be explored in future research.

The effects of turmeric and curcumin on NO are unclear. In the current study, TUR $\mathrm{R}_{\text {sim }}$ prevented a significant stimulatory effect of LPS on NO production, but did not result in significantly lower NO than in stimulated control explants at any point. This effect appears to result from a slightly (non-significantly) elevated media NO prior to stimulation with LPS, and does not provide support for an inhibitory effect of $\mathrm{TUR}_{\text {sim }}$ on NO production. The $\mathrm{IC}_{50}$ of an ethanolic extract of $C$. aromatica on LPS-induced NO production in murine macrophages is $12.27 \mu \mathrm{g} / \mathrm{mL}$ [19]. Using the same model, others report an $\mathrm{IC}_{50}$ of $23.4 \mu \mathrm{g} / \mathrm{mL}$ of a methanolic extract of C. zedoaria [20]. These exposure rates are in reasonable agreement with that of the current study, but we perhaps did not observe this effect because the biological extraction procedure modified the bioactivity of our test material. Also, the authors of the former studies utilized a different varieties of turmeric than that used in the current study, and the extracts were applied to macrophages rather than cartilage explants; all these factors may have contributed to the differing results of the current study. Others have explored the inhibitory effect of a water extract of C. longa on murine macrophages [21], and report that significant inhibition of LPS-induced NO was not measured until exposure rates exceeding $150 \mu \mathrm{g} / \mathrm{mL}$ - a 10 -fold higher exposure rate than the highest rate in the current study. A methanolic and ethyl acetate extract inhibited $\mathrm{NO}$ at exposure rates of 25 and $6.25 \mu \mathrm{g} / \mathrm{mL}$ (respectively) [21]. 
There are no studies reporting effects of C. longa on production of LPS-induced NO in cartilage explants with which to compare our data, and no studies which seek to identify post-hepatic biotransformation products in this model. However, our data support a mild inhibitory effect of $\mathrm{TUR}_{\text {sim }}$ on LPS-induced NO production which may contribute to the anti-arthritic effect reported from turmeric [22, 23], curcumin [24-26], and other turmeric-based compounds [27-29].

.Calcein fluorescence is a well-established technique for comparing populations of live cells in a variety of tissues including arterial explants [30] and cartilage explants [31]. The significant decline in calcein fluorescence in unstimulated explants exposed to TURsim in the current study was not expected, and is contrary to evidence that curcumin protects against IL-1induced cell death in primary chondrocytes [32-34]. Thus, we do not have a strong basis from which to conclude that our observed decline in fluorescence indicates promotion of cell death. An alternative explanation may be found in the well-documented stimulatory effect of curcumin [35-39] and its post-hepatic metabolite tetrahydrocurcumin [40] on autophagy. Autophagy is a physiological process which facilitates organized disassembly of damaged proteins and organelles in order to preserve energy balance and tissue homeostasis [41]. Non-selective autophagy plays a central role in bulk turnover of cytoplasm and sequesters various compounds that can influence calcein fluorescence into lysosomes. This has been demonstrated in HeLa cells for which calcein-AM was utilized to estimate cytosolic labile iron; autophagic degradation of ferruginous material resulted in sequestering of labile iron into lysosomes, and subsequent decrease in calcein fluorescence (and underestimate of intracellular labile iron) [42]. It is also plausible that $\mathrm{TUR}_{\text {sim }}$ may have contributed to decline in calcein fluorescence by promotion of cytotoxicity, as autophagy is a well-known mechanism for cell death under some circumstances [42, 43]. It not known if augmented autophagy contributed to the observed decline in calcein fluorescence in the current study, but this should be investigated in future research. Furthermore, future studies should also include an estimate of non-viable cells [eg. Staining of non-viable cells with ethidium homodimer-1] [9] and/or apoptosis [TUNEL assay] [44].

The methods used to test our hypothesis were designed to improve upon more conventional extraction methods for in vitro studies by incorporating effects of gastrointestinal digestion, hepatic metabolism, and diffusion across biological membranes. In addition to the limitations previously acknowledged, these methods are also limited by the cross-species use of cartilage from swine, and liver microsomes from rat. Porcine articular cartilage is significantly thinner $(1.2$ vs $1.8 \mathrm{~mm}$, respectively) and more permeable (6.3 vs $2.0 \times 10^{-16} \mathrm{~m}^{4} /$ Ns, respectively) than human cartilage [45]. Thus results reported herein may differ from that which might be observed with human cartilage. Furthermore, rat liver microsomes contain approximately $50 \%$ of the amount of lipid per mg protein than human liver microsomes [46], and enzymatic activity of microsomes have long been known to differ with developmental age [47] and species $[47,48]$. There are also notable differences between rat and human microsomal metabolism of compounds [32] which may also influence interpretation of our results within the context of human inflammation. The extent to which these limitations influence interpretation of data in the current study should be explored in future in vivo studies. These studies should also seek to validate the simulated digestion and biotransformation of oral turmeric by quantifying the levels and distribution of its active components in blood and articulating joints of pre-clinical animal models. In addition, the results reported herein are in response to LPS, and not to the endogenous pro-arthritis stimulus of interleukin-1 $\beta$ (IL-1) [49]. While IL-1 undoubtedly participates in the complex catabolic and pro-inflammatory signaling in OA, a recent review has concluded its contention as the prototypical catalyst for disease initiation and progression is in decline [50]. However, it may be of value to conduct further studies using IL-1 as the pro-inflammatory stimulus in order to compare cartilage responses to those reported in the current study.

\section{Conclusion}

A biological extract of turmeric reduces inflammatory responses of cartilage to LPS and contributes to the literary evidence for use of the spice to reduce articular inflammation and catabolism. The reason for decline in calcein fluorescence in $\mathrm{TUR}_{\text {sim-exposed cartilage explants is not }}$ known, but should be explored in further research.

\section{Abbreviations \\ GAG: Glycosaminoglycan; h: Hours; IL: Interleukin; LPS: Lipopolysaccharide; NADPH: Nicotinamide adenine dinucleotide; NO: Nitric oxide; \\ $\mathrm{PGE}_{2}$ : Prostaglandin $\mathrm{E}_{2} ; \mathrm{TUR}_{\text {sim: }}$ : Simulated biological extract of turmeric}

\section{Acknowledgements \\ Not applicable.}

\section{Authors' contributions}

WP performed all experiments, analyzed and interpreted all data, and was a major contributor in writing the manuscript. LSK contributed substantially to study design. Both authors read and approved the final manuscript.

\section{Funding}

Research funding provided by Selected Bioproducts Inc. (Guelph, Ontario Canada). Funding body did not participate in the design of the study or collection, analysis, or interpretation of data or in writing the manuscript.

\section{Availability of data and materials}

The datasets used and/or analysed during the current study are available from the corresponding author on reasonable request. 


\section{Ethics approval and consent to participate}

Not applicable.

\section{Consent for publication}

Not applicable.

\section{Competing interests}

The authors declare that they have no competing interests.

\section{Author details}

'Department of Animal Biosciences, University of Guelph, Guelph, ON N1G 2W1, Canada. ${ }^{2}$ Department of Plant Agriculture, University of Guelph, Guelph, ON, Canada.

\section{Received: 22 April 2019 Accepted: 28 August 2019}

\section{Published online: 11 September 2019}

\section{References}

1. Arora RB, Kapoor V, Basu N, Jain AP. Anti-inflammatory studies on Curcuma longa (turmeric). Indian J Med Res. 1971;59:1289-95.

2. Chandra D, Gupta SS. Anti-inflammatory and anti-arthritic activity of volatile oil of Curcuma longa (Haldi). Indian J Med Res. 1972;60:138-42.

3. Daily JW, Yang M, Park S. Efficacy of turmeric extracts and curcumin for alleviating the symptoms of joint arthritis: a systematic review and metaanalysis of randomized clinical trials. J Med Food. 2016:19:717-29.

4. Chin KY. The spice for joint inflammation: anti-inflammatory role of curcumin in treating osteoarthritis. Drug Des Dev Ther. 2016;10:3029-42.

5. Henrotin $Y$, Clutterbuck AL, Allaway D, Lodwig EM, Harris P, Mathy-Hartert $\mathrm{M}$, et al. Biological actions of curcumin on articular chondrocytes. Osteoarthr Cart. 2010:18:141-9.

6. Peddada KV, Peddada KV, Shukla SK, Mishra A, Verma V. Role of curcumin in common musculoskeletal disorders: a review of current laboratory, translational, and clinical data. Orth Surg. 2015;7:222-31.

7. Clutterbuck AL, Mobasheri A, Shakibaei M, Allaway D, Harris P. Interleukin1 beta-induced extracellular matrix degradation and glycosaminoglycan release is inhibited by curcumin in an explant model of cartilage inflammation. Ann New York Acad Sci. 2009;1171:428-35.

8. Mathy-Hartert M, Jacquemond-Collet I, Priem F, Sanchez C, Lambert C, Henrotin $Y$. Curcumin inhibits pro-inflammatory mediators and metalloproteinase-3 production by chondrocytes. Inflam Res. 2009;58: 899-908.

9. Pearson W, Fletcher RS, Kott LS, Hurtig MB. Protection against LPS-induced cartilage inflammation and degradation provided by a biological extract of Mentha spicata. BMC Comp Alt Med. 2010;10:19.

10. Rininger JA, Kickner S, Chigurupati P, McLean A, Franck Z. Immunopharmacological activity of Echinacea preparations following simulated digestion on murine macrophages and human peripheral blood mononuclear cells. J Leuk Biol. 2000;68:503-10.

11. Pearson W, Orth MW, Karrow NA, Maclusky NJ, Lindinger MI. Antiinflammatory and chondroprotective effects of nutraceuticals from Sasha's Blend in a cartilage explant model of inflammation. Mol Nutr Food Res. 2007a;51:1020-30.

12. Pearson W, Orth MW, Lindinger MI. Differential anti-inflammatory and chondroprotective effects of simulated digests of indomethacin and an herbal composite (Mobility) in a cartilage explant model of articular inflammation. J Vet Pharmacol Ther. 2007b;30:523-33.

13. Riley RJ, Leeder JS. In vitro analysis of metabolic predisposition to drug hypersensitivity reactions. Clin Exp Immunol. 1995:99:1-6.

14. Cavaleri F. Presenting a new standard drug model for turmeric and its prized extract, curcumin. Int J Inflam. 2018;5023429. https://doi.org/1 $0.1155 / 2018 / 5023429$.

15. Goel A, Kunnumakkara AB, Aggarwal BB. Curcumin as "Curecumin": from kitchen to clinic. Biochem Pharm. 2008;75:787-809.

16. Ireson C, Orr S, Jones DJ, Verschoyle R, Lim CK, Luo JL, Howells L, et al. Characterization of metabolites of the chemopreventive agent curcumin in human and rat hepatocytes and in the rat in vivo, and evaluation of their ability to inhibit phorbol ester-induced prostaglandin E2 production. Cancer Res. 2001;61:1058-64.

17. Pan MH, Huang TM, Lin JK. Biotransformation of curcumin through reduction and glucuronidation in mice. Drug Metab Dispos. 1999;27:486-94.
18. Tayyem RF, Heath DD, Al-Delaimy WK, Rock CL. Curcumin content of turmeric and curry powders. Nutr Cancer. 2006;55:126-31.

19. Anuthakoengkun A, Itharat A. Inhibitory effect on NO production and free radical scavenging activity of Thai medicinal plants in osteoarthritic knee treatment. J Med Assoc Thai. 2014;97:S116-24.

20. Lee TK, Trinh TA, Lee SR, Kim S, So HM, Moon E, et al. Bioactivity-based analysis and chemical characterization of anti-inflammatory compounds from Curcuma zedoaria rhizomes using LPS-stimulated RAW264.7 cells. Bioorg Chem. 2018;82:26-32.

21. Kawasaki K, Okuda-Hanafusa C, Aoyagi M, Taoka K, Yamamoto N, Muroyama K, et al. Inhibitory effect of the compounds from the water extract of Curcuma longa on the production of PGE2 and NO in a macrophage cell line stimulated by LPS. Biosci Biotech Biochem. 2018; 82:2109-17

22. Funk JL, Frye JB, Oyarzo JN, Kuscuoglu N, Wilson J, McCaffrey G, Stafford G, Chen G, Lantz RC, Jolad SD, Sólyom AM, Kiela PR, Timmermann BN. Efficacy and mechanism of action of turmeric supplements in the treatment of experimental arthritis. Arthritis Rheum. 2006a;54:3452-64.

23. Karlapudi V, AW PM, Sengupta K, Davis BA, Raychaudhuri SP. A PlaceboControlled Double-Blind Study Demonstrates the Clinical Efficacy of a Novel Herbal Formulation for Relieving Joint Discomfort in Human Subjects with Osteoarthritis of Knee. J Med Food. 2018;21:511-20.

24. Sun Z, Wei T, Zhou X. Liposomes encapsulated dimethyl curcumin regulates dipeptidyl peptidase I activity, gelatinase release and cell cycle of spleen lymphocytes in-vivo to attenuate collagen induced arthritis in rats. Int Immunopharmacol. 2018:65:511-21.

25. Sun Y, Liu W, Zhang H, Li H, Liu J, Zhang F, et al. Curcumin Prevents Osteoarthritis by Inhibiting the Activation of Inflammasome NLRP3. J Interferon Cytokine Res. 2017;37:449-55

26. Naz Z, Ahmad FJ. Curcumin-loaded colloidal carrier system: formulation optimization, mechanistic insight, ex vivo and in vivo evaluation. Int J Nanomed. 2015;10:4293-307.

27. Yimam M, Lee YC, Moore B, Jiao P, Hong M, Nam JB, et al. UP1304, a botanical composition containing two standardized extracts of Curcuma longa and Morus alba, mitigates pain and inflammation in adjuvant-induced arthritic rats. Pharmacog Res. 2016a;8:112-7.

28. Yimam M, Lee YC, Moore B, Jiao P, Hong M, Nam JB, et al. Analgesic and antiinflammatory effects of UP1304, a botanical composite containing standardized extracts of Curcuma longa and Morus alba. J Integr Med. 2016b;14:60-8.

29. Funk JL, Oyarzo JN, Frye JB, Chen G, Lantz RC, Jolad SD, Sólyom AM, Timmermann BN. Turmeric extracts containing curcuminoids prevent experimental rheumatoid arthritis. J Nat Prod. 2006b;69:351-5.

30. O'Neill L, Rooney P, Molloy D, Connolly M, McCormick J, Mccarthy G, et al. Regulation of Inflammation and Angiogenesis in Giant Cell Arteritis by Acute-Phase Serum Amyloid A. Arthritis Rheumatol. 2015;67:2447-256.

31. Kallemeyn NA, Grosland NM, Magnotta WA, Martin JA, Pedersen DR. Arthroscopic lens distortion correction applied to dynamic cartilage loading. lowa Orthop J. 2007;27:52-7.

32. Li X, Feng K, Li J, Yu D, Fan Q, Tang T, et al. Curcumin inhibits apoptosis of chondrocytes through activation ERK1/2 signaling pathways induced autophagy. Nutrients. 2017;9:E414.

33. Zhang G, Cao J, Yang E, Liang B, Ding J, Liang J, et al. Curcumin improves age-related and surgically induced osteoarthritis by promoting autophagy in mice. Biosci Rep. 2018;38:BSR20171691.

34. Zhao P, Cheng J, Geng J, Yang M, Zhang Y, Zhang Q, et al. Curcumin protects rabbit articular chondrocytes against sodium nitroprusside-induced apoptosis in vitro. Eur J Pharmacol. 2018;828:146-53.

35. Shakeri A, AFG C, Panahi Y, Mohajeri M, Sahebkar A. Curcumin: A naturally occurring autophagy modulator. J Cell Physiol. 2019;234:5643-54.

36. Xu JM, Ding HR, Li ZX, Wang HJ. Relationship between Autophagy and Curcumin-induced Anticancer Effect. Zhongguo Yi Xue Ke Xue Yuan Xue Bao. 2018;40:568-72

37. Yan P, Sun $X$, Chen X, Chen Y, Wang X, Su D, et al. The polyphenolic compound curcumin conjugation with an alkyne moiety in the process of autophagy. Am J Chinese Med. 2018;46:673-87.

38. Zhu Y, Bu S. Curcumin induces autophagy, apoptosis, and cell cycle arrest in human pancreatic cancer cells. Evid Based Complement Alternat Med. 2017; 2017:5787218.

39. Veeran S, Shu B, Cui G, Fu S, Zhong G. Curcumin induces autophagic cell death in Spodoptera frugiperda cells. Pest Biochem Physiol. 2017; 139:79-86. 
40. Song G, Lu H, Chen F, Wang Y, Fan W, Shao W, et al. Tetrahydrocurcumininduced autophagy via suppression of PI3K/Akt/mTOR in non-small cell lung carcinoma cells. Mol Med Rep. 2018;17:5964-9.

41. Yonekawa T, Thorburn A. Autophagy and cell death. Essays Biochem. 2013; 55:105-17.

42. Tenopoulou M, Kurz T, Doulias PT, Galaris D, Brunk UT. Does the calcein-AM method assay the total cellular 'labile iron pool' or only a fraction of it? Biochem J. 2007:403:261-6.

43. Anding AL, Baehrecke EH. Autophagy in Cell Life and Cell Death. Curr Top Dev Biol. 2015;114:67-91.

44. Duesterdieck-Zellmer KF, Driscoll N, Ott JF. Concentration-dependent effects of tiludronate on equine articular cartilage explants incubated with and without interleukin-1B. Am J Vet Res. 2012;73:1530-9.

45. Taylor SD, Tsiridis E, Ingham E, Jin Z, Fisher J, Williams S. Comparison of human and animal femoral head chondral properties and geometries. Proc Inst Mech Eng H. 2012;226:55-62.

46. Benga G, Pop VI, lonescu M, Hodârnău A, Tilinca R, Frangopol PT. Comparison of human and rat liver microsomes by spin label and biochemical analyses. Biochim Biophys Acta. 1983;750:194-9.

47. Greengard O. Enzymic differentiation of human liver: comparison with the rat model. Ped Res. 1977;11:669-76.

48. Johlin FC, Swain E, Smith C, Tephly TR. Studies on the mechanism of methanol poisoning: purification and comparison of rat and human liver 10-formyltetrahydrofolate dehydrogenase. Mol Pharmacol. 1989;35:745-50.

49. Hernandez G, Mills TS, Rabe JL, Chavez JS, Kuldanek S, Kirkpatrick G, Noetzli L, Jubair WK, Zanche M, Meyers JR, Stevens BM, Fleenor CJ, Adane B, Dinarello CA, Ashton J, Jordan CT, Di Paola J, Hagman JR, Holers VM, Kuhn KA, Pietras EM. Pro-inflammatory cytokine blockade attenuates myeloid expansion in a murine model of rheumatoid arthritis. Haematologica. 2019 https://doi.org/10.3324/haematol.2018.197210 Epub ahead of print.

50. Vincent TL. IL-1 in osteoarthritis: time for a critical review of the literature. F1000Res. 2019;8. https://doi.org/10.12688/f1000research.1 8831.1 eCollection 2019.

\section{Publisher's Note}

Springer Nature remains neutral with regard to jurisdictional claims in published maps and institutional affiliations.

Ready to submit your research? Choose BMC and benefit from:

- fast, convenient online submission

- thorough peer review by experienced researchers in your field

- rapid publication on acceptance

- support for research data, including large and complex data types

- gold Open Access which fosters wider collaboration and increased citations

- maximum visibility for your research: over $100 \mathrm{M}$ website views per year

At $\mathrm{BMC}$, research is always in progress.

Learn more biomedcentral.com/submissions 